\title{
ANALISIS YURIDIS PERAN PROFESI PEKERJA SOSIAL DALAM UNDANG- UNDANG NOMOR 11 TAHUN 2012
}

\author{
Hari Harjanto Setiawan* dan Makmur Sunusi ${ }^{* *}$
}

Pusat Penelitian dan Pengembangan Kesejahteraan Sosial, Kementerian Sosial RI, Jakarta Timur Jalan Dewi Sartika No. 200 Cawang III, Jakarta Timur 13630

Bagian Hukum Pidana, Fakultas Hukum Universitas Muhammadiyah Jakarta, Jakarta Selatan Jalan K.H. Ahmad Dahlan, Cirendeu, Jakarta Selatan 15419

\begin{abstract}
Act Number 11 of 2012 involving social work profession in dealing with children in conflict with the law $(A B H)$. This paper will discuss the role of social worker as professional that will work closely with legal professional. Clarity of roles is expected to avoid collisions with each other due to the jobs involved have some similar roles and functions. Public prosecutor, community worker and social worker are expected to work in harmony in performing their duties.
\end{abstract}

Keywords: children, professional, social workers.

\section{Intisari}

Undang-Undang Nomor 11 Tahun 2012 melibatkan profesi pekerjaan sosial dalam menangani Anak yang Berkonflik dengan Hukum (ABH). Tulisan ini akan membahas peranan pekerja sosial sebagai sebuah profesi yang akan bekerja sama dengan profesi hukum. Kejelasan peranan ini diharapkan tidak terjadi benturan satu sama lain karena profesi yang terlibat mempunyai peran dan fungsi masing-masing. Jaksa, pendamping kemasyarakatan dan pekerja sosial diharapkan dapat berjalan harmonis dalam melakukan tugasnya.

Kata Kunci: anak, profesional, pekerja sosial.

\section{Pokok Muatan}

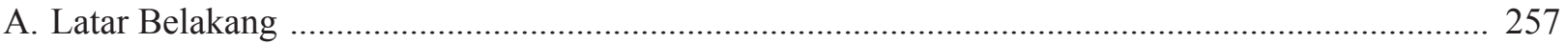

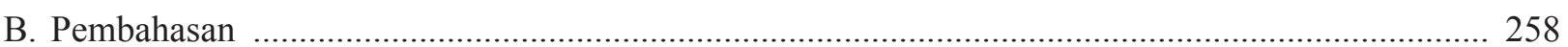

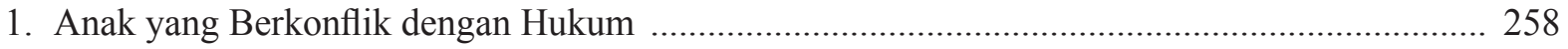

2. Restorative Justice sebagai Tujuan Praktik Pekerjaan Sosial ................................................... 259

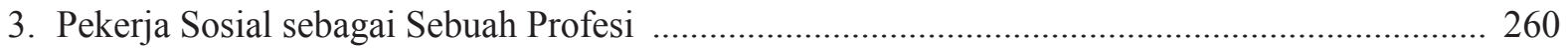

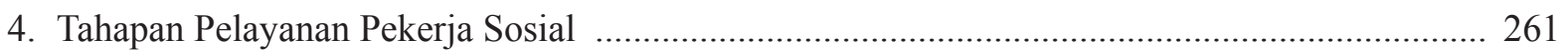

5. Peran Pekerja Sosial Menangani Anak yang Berkonflik dengan Hukum ................................... 264

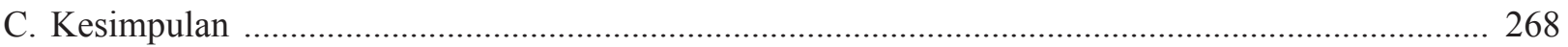

* Alamat korespondensi: hari_harjanto@yahoo.com

** Alamat korespondensi: maksus19@yahoo.com 


\section{A. Pendahuluan}

Undang-Undang Nomor 11 Tahun 2012 telah ditetapkan dan diberlakukan pada tahun 2014. Undang-Undang ini menyempurnakan undang-undang sebelumnya yaitu Undang-Undang Nomor 3 Tahun 1997 tentang Pengadilan Anak. Pada Undang-Undang Nomor 11 Tahun 2012 mencantumkan Profesi Pekerjaan Sosial dalam menangani permasalahan anak yang berkonflik dengan hukum. Sehingga perlu adanya kajian yang mendalam mengenai profesi pekerja sosial agar semua profesi yang terlibat di dalamnya dapat harmonis dalam menjalankan tugasnya.

Pada praktek pekerjaan sosial di Indonesia, ABH sudah menjadi permasalahan yang serius karena dari tahun ke tahun jumlahnya cukup tinggi. Berdasarkan data dari Ditjen Lembaga Pemasyarakatan serta Kementerian Hukum dan HAM RI, menyatakan bahwa jumlah anak yang berada di lembaga penahanan dan lembaga pemasyarakatan pada tahun 2011 berjumlah 6.141, tahun 2012 berjumlah 5.226 dan tahun 2013 berjumlah 4.953 orang anak. ${ }^{1}$ Anak melakukan tindak pidana sesungguhnya karena kondisi obyektif yang melingkupi diri anak dan lingkungannya. Laporan Pendataan Pusat Data dan Informasi Kementerian Sosial RI menunjukkan bahwa, jumlah anak nakal sebanyak 146.228 anak. $^{2}$

Data hasil penelitian BPS tahun 2010 tentang tindak kriminal anak menunjukkan bahwa tindak pidana pencurian adalah jenis kenakalan atau tindak pidana yang paling sering dilakukan oleh anak-anak. Sebanyak 200 anak pidana (narapidana anak) yang diteliti, 120 anak diantaranya atau sekitar $60 \%$ adalah pelaku tindak pidana pencurian. Jenis tindak pidana menonjol lainnya berturut- turut adalah penyalahgunaan narkoba 9,5\%, perkosaan/pencabulan $6 \%$, kecelakaan lalu lintas yang mengakibatkan kematian orang lain 5\%, pengeroyokan $4 \%$ dan penganiayaan $4 \%{ }^{3}$

Dampak negatif dari proses hukuman dialami oleh anak selain secara psikologis juga secara sosial. Seperti kasus ABH yang dialami oleh Raju dalam Koran kompas dengan judul "Raju Masih Kecil Kok Sudah Dipenjara". ${ }^{4}$ Setelah proses hukuman selesai, permasalahan anak tidak akan berhenti dengan sendirinya. Pemberian label oleh masyarakat yang tidak baik kepada anak yang dijatuhi hukuman merupakan permasalahan tersendiri. Setelah keluar dari penjara, anak diasingkan oleh lingkungan sosial, lingkungan bermainnya dan lingkungan keluarganya. Hal itu dapat menyebabkan anak merasa sangat terasing dan terbuang dari lingkungan sosialnya. Kondisi yang demikian jauh dari terpenuhinya hak-hak anak. ${ }^{5}$ Apabila peradilan harus dilaksanakan, diharapkan hasilnya adalah memulihkan, bukan dijatuhkan hukuman pidana penjara. Anak yang berada di dalam lembaga juga harus terpenuhi hak-hak anak lainnya, seperti kesehatan, hak atas proses asimilasi dan hak berpartisipasi dalam kegiatan pembinaan berdasarkan ketentuan perundang-undangan yang berlaku. Inilah yang mendasari perlunya dikembangkan pendekatan yang berkeadilan atau restorative justice. Pada pendekatan ini ada tiga pilar yang menjadi titik perhatian perkara dan diharapkan menjadi sentral dalam penyelesaian suatu perkara pidana adalah saksi, korban, pelaku dan masyarakat. ${ }^{6}$

Kebijakan pemerintah Indonesia dalam mengatasi permasalahan tersebut antara lain, pada tahun 1990 telah meratifikasi konvensi hak anak

Direktorat Jenderal Pemasyarakatan (Ditjen PAS) Kementerian Hukum dan HAM, "Sistem Data Based Pemasyarakatan", http://smslap. ditjenpas.go.id/public/arl/current/monthly, diakses 21 Januari 2011.

Pusat Data dan Informasi Kementerian Sosial RI, "Data Penyandang Masalah Kesejahteraan Sosial Anak Nakal (AN)", http://www.kemsos. go.id/unduh/PMKS/Rekap PMKS 2012.pdf, diakses 19 September 2014.

Kerjasama Kementerian Pemberdayaan Perempuan dan Perlindungan Anak dengan Badan Pusat Statistik, 2011, Profil Anak Indonesia 2011, Miftahur Rizky, Jakarta, hlm. 81.

Khaeruddin,"Raju Masih Kecil Kok Sudah Dipenjara?", http://sarapanpagi.fr.yuku.com/topic/568/Raju-Masih-Kecil-Kok-Sudah-Dipenjara, diakses 19 September 2014.

Undang-Undang Nomor 23 Tahun 2002 tentang Perlindungan Anak (Lembaran Negara Republik Indonesia Tahun 2002 Nomor 109, Tambahan Lembaran Negara Republik Indonesia Nomor 4235).

6 Eva Achjani Zulva, 2009, Keadilan Restoratif di Indonesia, Disertasi, Fakultas Hukum, Universitas Indonesia, Jakarta. 
melalui Keputusan Presiden RI Nomor 36 dan diundangkan melalui Undang-Undang Perlindungan anak Nomor 23 Tahun 2002 yang di amandemen tahun 2014, kemudian diikuti oleh perda masingmasing daerah. Peraturan lain terkait, UndangUndang Nomor 3 Tahun 1997 tentang Pengadilan Anak dan undang-undang Nomor 39 Tahun 1999 tentang hak asasi manusia. Undang-Undang Peradilan Anak dianggap tidak berpihak pada anak, sehingga dilakukan revisi menjadi Undang-Undang Nomor 11 tahun 2012 tentang Sistem Peradilan Pidana Anak. Peraturan tersebut baru diberlakukan setelah dua tahun ditetapkan yaitu bulan Agustus 2014. Pelaksanaan program yang tidak terkoordinasi menjadi permasalahan dalam penerapan kebijakan. Untuk mengoordinasikan antar sektor, dibuatlah kesepakatan bersama antara Depsos, Depkum dan HAM, Depdiknas, Depkes, Depag, dan Kepolisian tentang Perlindungan dan Rehabilitasi Sosial Anak yang Berhadapan dengan Hukum. ${ }^{7}$

Melihat permasalahan tersebut, pekerja sosial sebagai sebuah profesi dapat berperan dalam menangani anak yang berkonflik dengan hukum. Terlebih lagi bahwa profesi ini dimasukkan dalam Undang-Undang Nomor 11 Tahun 2012, sehingga kedudukan pekerja sosial sudah mempunyai dasar hukum yang jelas. Tulisan ini akan menguraikan peran pekerja sosial dalam UU tersebut dari sisi profesi pekerjaan sosial. Berdasarkan latar belakang masalah diatas muncul rumusan masalah yang menarik untuk dilakukan penelitian yakni: Pertama, bagaimana gambaran anak yang berkonflik dengan hukum dalam UU tersebut, apa tujuan praktek pekerjaan sosial dalam menangani ABH? Kedua, apakah syarat-syarat sebagai seorang pekerja sosial profesional? Ketiga, bagaimana tahapan pelayanan profesi pekerja sosial? Keempat, apa peranan pekerja sosial dalam menangani $\mathrm{ABH}$ ?

\section{B. Pembahasan}

\section{Anak yang Berkonflik dengan Hukum}

Anak yang berhadapan dengan hukum menurut Undang-Undang Nomor 11 Tahun 2012 mencakup pelaku, korban dan saksi, namun dalam tulisan ini fokus pada anak yang berkonflik dengan hukum (anak pelaku). Definisi anak yang berkonflik dengan hukum dalam UU tersebut adalah anak yang telah berumur 12 (dua belas) tahun, tetapi belum berumur 18 (delapan belas) tahun yang diduga melakukan tindak pidana. Artikel ini melihat definisi tersebut dari berbagai pandangan antara lain: perkembangan anak, hak asasi manusia, dan kesejahteraan sosial.

Menurut pandangan perkembangan anak, masa ini yang paling mendasar dan penting dalam membentuk masa selanjutnya yang dipengaruhi oleh lingkungannya. Perkembangan anak tidak selamanya baik, sehingga anak terpaksa berkonflik dengan hukum yang dalam perkembangan anak disebut delikuen. ${ }^{8}$ Perilaku anti sosial ini antara lain, "it includes acts prohibited by the criminal law, such as theft, burglary, robbery, violence, vandalism, and drug use". ${ }^{9}$

Pandangan hak asasi manusia mengenai hal ini adalah "a claim right held by individuals in virtue of the fact that they are human beings. Human rights are not tied to a particular social class, professional group, cultural collective, racial group, gender, or any other exclusive category". ${ }^{10}$ Definisi anak adalah seseorang yang belum berusia 18 (delapan belas) tahun, yang telah disepakati dalam Convention on the Right of the Child. ${ }^{11}$ Perlindungan khusus tersebut lebih ditegaskan dalam konvensi hak anak bahwa, "Tidak seorang anak akan secara tidak sah atau sewenangwenang, direnggut kemerdekaannya. Penangkapan, penahanan, atau pemenjaraan anak akan dilakukan

Kesepakatan Bersama Menteri Sosial RI, Menteri Hukum dan HAM RI, Menteri Pendidikan Nasional RI, Menteri Kesehatan RI, Menteri Agama RI dan Kepolisian Negara RI, Nomor: 12/PRS-2/KPTS/2009, Nomor: M.HH.04.MH.03.02.Th.2009, Nomor: 11/XII/KB/2009, Nomor: 1220/Menkes/SKB/XII/2009, Nomor: 06/XII/2009, Nomor: B/43/XII/2009 tentang Perlindungan dan Rehabilitasi Sosial Anak yang Berhadapan dengan Hukum.

W. A. Gerungan, 1988, Psikologi Sosial. Eresco, Bandung, hlm. 199.

Farrington, 1988, Youth Crime and Antisocial Behaviour, Psychology Press Ltd., Cambridge, hlm. 355

Tony Ward, et al., 2007, Human rights and Correctional Clinical Practice, Elsevier, Melbourne, hlm. 630.

UNICEF, “Konvensi Hak Anak", http://www.unicef.org/magic/media/documents/CRC_bahasa_indonesia_version.pdf, diakses 22 September 2014. 
sesuai hukum dan diterapkan hanya sebagai langkah terakhir dan untuk masa paling singkat yang dimungkinkan". Sebaiknya penerapan pemidanaan yang tepat terhadap anak sebagai pelaku tindak pidana berupa pemidanaan edukatif dalam sistem peradilan pidana anak. ${ }^{12}$ Namun pemidanaan yang edukatif ini mengalami kendala karena pegawai lembaga pemasyarakatan tidak memiliki keahlian khusus untuk menangani persoalan anak. ${ }^{13}$

Pandangan Kesejahteraan Sosial, memperlihatkan bahwa $\mathrm{ABH}$ disebabkan karena pelanggaran terhadap hukum atau tindak kriminal yang diperbuatnya. ${ }^{14}$ Pengertian tersebut menunjukkan pentingnya peranan nilai atau norma dalam suatu masyarakat yang menjadi bagian dari hukum yang ditetapkan oleh suatu negara. Namun lebih luas lagi bahwa $\mathrm{ABH}$ adalah anak yang melanggar nilai atau norma dalam masyarakat, sehingga keterpisahan anak dari nilai atau norma dalam suatu masyarakat termasuk di dalamnya adalah nilai atau norma keluarga merupakan indikator awal pelanggaran hukum. Konsep kesejahteraan sosial yakni suatu keadaan yang lebih baik, kebahagiaan dan kemakmuran pada individuals, families, groups, communities and even whole Societies. ${ }^{15}$ Pada konteks kesejahteraan $\mathrm{ABH}$, child welfare encompasses programs and policies oriented toward the protection, care, and healthy development of Children. ${ }^{16}$ Pelanggaran hukum disebut juga perilaku menyimpang "Conceive of deviance as a collection of conditions, persons, or acts that society disvalues, finds offensive, or condemns" ${ }^{17}$ Permasalahan tersebut membutuhkan intervensi psikososial adalah intervensi pekerjaan sosial profesional yang menekankan pada penggunaan metode pekerjaan sosial dengan individu, keluarga (social casework) dan kelompok (social group work). ${ }^{18}$ Anak yang melakukan tindak kriminal dianggap sebagai deviation karena ada penyimpangan terhadap kaidah dan nilai-nilai dalam kehidupan masyarakat. ${ }^{19}$

\section{Restorative Justice sebagai Tujuan Praktek Pekerjaan Sosial}

Tujuan praktek pekerjaan sosial adalah menciptakan kondisi restorative justice. ${ }^{20}$ Pada proses untuk menciptakan kondisi restorative justice ini pekerja sosial berusaha menyatukan kembali anak dengan orang tuanya dan masyarakat. Penyatuan anak kembali secara sosial (social reintegration) is often understood as the support given to offenders during their re-entry into society following imprisonment. ${ }^{21}$ Integrasi sosial berarti adanya keterikatan dengan merasakan menjadi bagian dari kehidupan bersama dapat memberi pengalaman kepada perorangan untuk memperoleh ketenteraman psikologis tertentu dan memberikan arti pada kehidupannya. ${ }^{22}$ Pendekatan ini merupakan paradigma penyelesaian tindak pidana dengan mengedepankan mediasi dan rekonsiliasi dan mengupayakan diversi. ${ }^{23}$ Pada prosesnya, komponen yang dipertemukan yaitu "the individual victim, the offender and the Community: ${ }^{24}$ the victim, the victim's family, the offender, the offender's family, and the Community", ${ }^{25}$ sehingga pendampingan

\footnotetext{
2 Rinita, 2012, Analisis Yuridis Penerapan Pemidanaan Edukatif terhadap Anak Sebagai Pelaku Tindak Pidana,Tesis, Fakultas Hukum, Universitas Indonesia, Jakarta.

13 Mukhamad Tri Setyobudi, 2012, Pembinaan Anak Pidana di Lembaga Pemasyarakatan Anak Tangerang, Tesis, Fakultas Hukum Universitas Indonesia, Jakarta.

Charles Zastro, 2004, Introduction to Social Welfare, Thomson Brooks/Cole, Michigan, hlm. 306. James Midgley, 1995, Social Development, The Developmental Perspective in Social Welfare, SAGE Publications, London, hlm. 14. NASW, 2005, NASW Standards for Social Work Practice in Child Welfare, NASW, Washington, hlm. 14. Marsal Clinard, et al., 2001, Sociology of Deviant Behaviour, Wadsworth Cengage Learning, Belmont, hlm. 6. Departemen Sosial RI, 2001, Intervensi Psikososial, Direktorat Kesejahteraan Anak, Jakarta, hlm.137. Soerjono Soekanto, 1993, Sosiologi Suatu Pengantar, Raja Grafindo Persada, Jakarta, hlm. 237.

United Nation Office on Drugs and Crime (UNODC), 2006, Handbook on Restorative Justice Programmes, UNODC, New York, hlm. 6. Currt T. Griffith, et al., 2007, The Social Reintegration of Offenders and Crime Prevention, The International Center for Criminal Law Reform and Criminal Justice Policy (ICCLR), Ottawa, hlm. 3.

Sutarso, 2005, Praktek Pekerjaan Sosial dalam Pembangunan Masyarakat, Balatbangsos, Jakarta, hlm. 184.

Sharon Detrick et al., 2008, Violence Against Children in Conflict with the Law, Defence For Children International, Amsterdam, hlm. 15. Mizrahi Terry, et al., 2008, Encyclopaedia of Social Work, NASW Press, Washington, hlm. 531.

Joan Shireman, 2003, Critical Issues in Child Welfare, Columbia University Press, New York, hlm. 377.
} 
pekerja sosial di masyarakat dilakukan untuk mencegah terjadinya anak yang berkonflik dengan hukum. ${ }^{26}$ Hal ini dilakukan untuk merubah status offender menjadi non-offender dalam rangka mewujudkan restorative justice. ${ }^{27}$

Restorative justice bertentangan dengan pemenjaraan yang merupakan bentuk keadilan yang retributive atau pembalasan. Hal ini kurang baik bagi perkembangan anak, sebagaimana dikemukakan oleh Bandura, bahwa: "that punishment does not stimulate or negate behaviours well as reinforcement; therefore, reinforcement is more important in development". ${ }^{28} \mathrm{Di}$ Indonesia bentuk pemenjaraan masih terlihat walaupun secara konsep sebenarnya pemasyarakatan merupakan filsafat reintegrasi sosial. ${ }^{29}$

Salah satu bentuk reintegrasi adalah penerapan diversi. Di Indonesia, setelah disahkan Undang-Undang Nomor 11 Tahun 2012 tentang Sistem Peradilan Pidana Anak, maka penerapan diversi dapat dilakukan oleh jaksa. ${ }^{30}$ Selain diversi, aktivitas integrasi adalah mengembalikan anak kepada keluarga, melanjutkan berhubungan dengan masyarakat, vokasional training dan pelayanan lain merupakan fondasi suksesnya reintegrasi anak kembali ke dalam kehidupan masyarakat. ${ }^{31}$ Keluarga dapat menjadi kelompok dukungan (family support) seperti dikemukakan Audio Commission mendefinisikan family support adalah "any activity or facility provided either by statutory agencies or by community groups or individuals aimed at providing advice and support to parents to help them bring up their Children". ${ }^{32}$

Dengan demikian seluruh pelayanan yang dilakukan untuk anak yang berkonflik dengan hukum, tujuan utamanya adalah anak dapat terintegrasi dalam kehidupan masyarakat. Sejalan dengan hal tersebut, proses reintegrasi dilakukan dengan cara sosialisasi melalui keluarga, masyarakat, kelompok-kelompok sebaya mereka, sekolah-sekolah, pelatihan kejuruan dan dunia kerja serta melalui organisasi sukarela. ${ }^{33}$

\section{Pekerja Sosial sebagai Sebuah Profesi}

Pekerjaan sosial bukan hanya pekerjaan amal namun merupakan profesi yang di dalamnya adalah ada tiga unsur pokok yaitu keilmuan, keterampilan dan nilai. Namun secara spesifik yang dimaksud pekerja sosial profesional pada Bagian ketiga Undang-Undang Nomor 11 Tahun 2012 tentang Sistem Peradilan Pidana Anak Pasal 66 menyatakan bahwa syarat-syarat untuk dapat diangkat sebagai Pekerja Sosial Profesional adalah berijazah paling rendah strata satu (S-1) atau diploma empat (D-4) di bidang pekerjaan sosial atau kesejahteraan sosial, berpengalaman kerja paling singkat 2 (dua) tahun di bidang praktik pekerjaan sosial dan penyelenggaraan kesejahteraan sosial, mempunyai keahlian atau keterampilan khusus dalam bidang pekerjaan sosial dan minat untuk membina, membimbing, dan membantu anak demi kelangsungan hidup, perkembangan fisik, mental, sosial, dan perlindungan terhadap anak, dan lulus uji kompetensi sertifikasi Pekerja Sosial Profesional oleh organisasi profesi di bidang kesejahteraan sosial.

Adapun tugas seorang pekerja sosial profesional terdapat pada Pasal 68 ayat (1) Pekerja Sosial Profesional bertugas membimbing, membantu, melindungi, dan mendampingi anak dengan melakukan konsultasi sosial dan mengembalikan kepercayaan diri Anak, memberikan pendampingan dan advokasi sosial,

\footnotetext{
Alit Kurniasari, 2009, Profil Pendamping dalam Perlindungan Anak Berkonflik dengan Hukum, P3KS Press, Jakarta, hlm. 30. David Smith, "Probation and Social Work", British Journal of Social Work, Vol. 7, Issue 4, 1977, hlm. 631.

Neil J. Salkind, 2006, Encyclopaedia of Human Development, Sage Publication, New Delhi, hlm. 157.

Iqrak Sulhin, "Filsafat (Sistem) Pemasyarakatan”, Jurnal Kriminologi Indonesia, Vol.7, No.1, Mei 2010, hlm.148.

Abdi Reza Fachlewi Junus, 2012, Peran Jaksa dalam Menerapkan Konsep Diversi terhadap Anak yang Berkonflik dengan Hukum, Tesis, Fakultas Hukum Universitas Indonesia, Jakarta, hlm. 151.

31 Don Cipriani, 2009, Children's Rights and the minimum Age of Criminal Responsibility A Global Perspective, Ashgate Publishing Limited, Bulington, hlm.9.

32 Mauren O'loughlin, et al., 2008, Transforming Social Work Practice: Social Work with Children and Families, Learning Matters Ltd., New York, hlm. 28.

33 United Nation Guidelines for Prevention of Juvenile Delinquency.
} 
menjadi sahabat Anak dengan mendengarkan pendapat Anak dan menciptakan suasana kondusif, membantu proses pemulihan dan perubahan perilaku Anak, membuat dan menyampaikan laporan kepada Pembimbing Kemasyarakatan mengenai hasil bimbingan, bantuan, dan pembinaan terhadap Anak yang berdasarkan putusan pengadilan dijatuhi pidana atau tindakan, memberikan pertimbangan kepada aparat penegak hukum untuk penanganan rehabilitasi sosial Anak, mendampingi penyerahan Anak kepada orang tua, lembaga pemerintah, atau lembaga masyarakat; dan melakukan pendekatan kepada masyarakat agar bersedia menerima kembali Anak di lingkungan sosialnya. Pada ayat (2) bahwa, "Dalam melaksanakan tugas sebagaimana dimaksud pada ayat (1), Pekerja Sosial Profesional dan Tenaga Kesejahteraan Sosial mengadakan koordinasi dengan Pembimbing Kemasyarakatan", ${ }^{34}$

Karakteristik profesionalisme pekerja sosial adalah penekanannya pada tiga dimensi yaitu kerangka pengetahuan, nilai dan keterampilan yang harus dikembangkan ketiga-tiganya secara seimbang dan simultan. Profesi lain, pada umumnya hanya menekankan pada dua aspeknya saja yaitu pengetahuan dan keterampilan praktek. Pekerja Sosial sejak semula mempunyai komitmen tinggi terhadap penanaman nilai dalam proses pendidikannya, serta merumuskan dirinya sebagai profesi atau disiplin yang bukan bebas nilai. Pekerja sosial berkiprah dalam suatu posisi nilai yang jelas dan eksplisit, seperti martabat manusia, keadilan sosial, keberpihakan kepada mereka yang tidak beruntung.

Pekerja Sosial menamakan dirinya "normative discipline". Pekerja Sosial lebih dari sekedar aktivitas teknis. Pekerja Sosial berada di luar lingkungan yang semakin dikuasai oleh birokrasi dan manajer, di mana akuntabilitas terhadap manajer lebih ditekankan dari pada akuntabilitas terhadap publik atau konsumen. Lingkungan praktek Pekerja Sosial tidak memungkinkan bagi diskresi, prakarsa, kreativitas, serta menemukan alternatif sesuai dengan komitmennya terhadap nilai.

Penekanan pada pengetahuan, keterampilan dan nilai mempunyai implikasi terhadap hakikat praktek Pekerjaan Sosial. Bila pengetahuan dipandang sebagai sama pentingnya dengan keterampilan, maka pemahaman sama pentingnya dengan kompetensi. Pekerja Sosial memandang dirinya sebagai pemikiran dan pekerja, serta sebagai orang yang harus membuat pertimbangan berdasarkan pengetahuan dan pengalaman sebelum bertindak. Situasi ini bertentangan dengan lingkungan praktek di mana manajer menentukan tujuan, sasaran dan arahan untuk mencapainya, dan menyingkirkan pertimbangan diskresioner dari Pekerja Sosial. Pekerja Sosial melakukan praktek dalam lingkungan pengaturan, panduan praktek, serta arahan administratif. Menghubungkan dan memperkuat pengetahuan, nilai dan keterampilan menimbulkan permasalahan tersendiri bagi Pekerja Sosial dalam lingkungan politik, birokrasi dan manajerial di mana pekerja sosial perlu menyesuaikan diri.

Pekerja Sosial yang menangani $\mathrm{ABH}$, harus melakukan tindakan-tindakan yang profesional sesuai dengan ketiga dimensi di atas. Pengetahuan berarti seorang pekerja sosial harus mempunyai latar belakang pendidikan pekerjaan sosial. Nilai berarti praktek pekerjaan sosial harus dilandasi dengan nilai-nilai tertentu yaitu kode etik praktek pekerjaan sosial. Keterampilan seorang pekerja sosial banyak dipengaruhi oleh semakin banyaknya praktek yang di lakukan (jam terbang).

\section{Tahapan Pelayanan Pekerja Sosial}

Tahapan-tahapan pekerja sosial profesional dalam menangani anak yang berkonflik dengan hukum adalah assessment, membuat rencana program aksi, implementasi program aksi, dan evaluasi.

\section{a. Assessment}

Pengertian assessment yaitu suatu

34 Undang-Undang Nomor 11 Tahun 2012 tentang Sistem Peradilan Pidana Anak (Lembaran Negara Republik Indonesia Tahun 2012 Nomor 153, Tambahan Lembaran Negara Republik Indonesia Nomor 5332). 
tahapan dalam proses pertolongan pekerja sosial berupa memahami suatu masalah dan kebutuhan ABH. Ada 4 (empat) pilar dasar assessment terhadap anak antara lain: normreferenced tests, interviews, observations, and informal assessment. ${ }^{35}$ Masalah merupakan kesulitan-kesulitan yang dihadapi individu maupun kelompok. Masalah sosial merupakan kesulitan-kesulitan yang dihadapi seseorang dalam keberfungsian sosial dan tugas-tugas kehidupannya, akibat dari pelanggaran norma dalam hubungan antara manusia dalam lingkungan. Garis besar penyebab masalah adalah sosial dan kultural dalam suatu masyarakat.

Prinsip-prinsip yang digunakan untuk mendefinisikan masalah yaitu: (1) masalah harus didefinisikan dalam suatu istilah disfungsi sosial yang spesifik, yang dimanifestasikan dalam tingkah laku yang spesifik. Masalah tingkah laku harus digambarkan sebagai hal yang mempercepat, mempertajam atau menetap primer dan sekunder; (2) pengertian dari masalah harus difungsikan dan difokuskan kepada lingkungan dan kepentingan umum; dan (3) walaupun pengertian atau definisi dari masalah harus menunjukkan kebutuhankebutuhan dan tugas-tugas itu tidak atau belum selesai, kesulitan-kesulitan yang dapat diselesaikan dalam beberapa cara tanpa pedoman masalah yang khusus.

\section{b. Membuat Rencana Program Aksi}

Rencana tersebut harus memuat pernyataan tentang tujuan atau hasil yang ingin dicapai melalui pelayanan manajemen kasus, yang sekaligus menunjukkan kondisi seperti apa yang ingin dicapai yang menandakan bahwa masalah kesejahteraan atau perlindungan anak telah ditangani. Rencana pelayanan harus mempertimbangkan dan menggambarkan: tujuan/sasaran pencapaian pelayanan, pemilihan area dan kegiatan pelayanan berikut pihak yang terlibat yang akan memberikan dampak paling baik terhadap penanganan masalah, prioritas penanganan berikut alternatifalternatif pemecahan masalah, rentang waktu pelaksanaan setiap kegiatan pelayanan dan kesepakatan para pihak yang terlibat dalam pelayanan dan keterlibatan keluarga anak.

Tujuan pencapaian di tingkat anak dan keluarga, dalam menyusun rencana pelayanan hendaknya dilakukan dengan melihat anak dalam konteks lingkungan ekologisnya, sebagaimana dilakukan dalam kerangka assessment. Anak berfokus pada adanya perubahan kondisi kesehatan, perilaku, kesejahteraan emosi dan psikososial, kelangsungan perkembangan, pencapaian bidang pendidikan, hubungan dengan teman, dan kelangsungan asuhan. Pelayanan untuk orang tua berfokus pada peningkatan kesehatan mental orang tua/ pengasuh, kemampuan mengatasi masalah, kemampuan melindungi dan mengasuh anak, kepedulian pada pengasuhan dan pendidikan anak, atau perbaikan kemampuan ekonomi. Pelayanan untuk keluarga dan lingkungan, berfokus pada perbaikan pola komunikasi dan interaksi dalam keluarga dan antar keluarga kerabat, kepedulian dan dukungan kerabat, dukungan dan keterlibatan lingkungan sekitar keluarga anak, hingga ke yang lebih luas seperti perbaikan keamanan lingkungan, pengawasan lingkungan oleh pemuka warga, pola interaksi komunitas yang lebih luas, norma dan nilai yang berkembang dalam masyarakat dan lain-lain.

Sering kali masalah yang dihadapi anak dan keluarga bersifat multi-dimensi dan kompleks, sehingga pemecahannya tak mungkin dapat dicapai hanya dengan mengandalkan pelayanan dari satu lembaga 
saja. Sejak dini mengidentifikasi lembagalembaga yang ada di wilayahnya yang berpotensi menjadi penyedia layanan dan sumber solusi atas masalah kesejahteraan anak, menjalin komunikasi, dan membangun kesepakatan kerjasama dalam kerangka manajemen kasus.

\section{c. Implementasi Program Aksi}

Setelah rencana pelayanan disepakati dan ditetapkan, seorang pekerja sosial sebagai manajer kasus berperan mengoordinasikan dan menyinkronkan pelaksanaannya agar proses pemulihan dan pemberdayaan anak beserta keluarganya dapat berjalan sesuai harapan. Manajer kasus berbekal kejelasan kesepakatan antar lembaga peserta case conference mendampingi dan mengawal anak memperoleh layanan sesuai tahap pelayanan yang telah direncanakan. Implementasi pelayanan dilakukan berdasarkan penetapan prioritas yang mencakup kegiatan sebagai berikut: Pertama, pendampingan dapat dilakukan kepada anak dan keluarga (apabila layanan yang diberikan berbasiskan masyarakat) atau dilakukan di lembaga (apabila layanan berbasis institusi). Kedua, layanan penempatan anak di shelter (rumah aman/perlindungan) bersifat sementara bagi anak yang membutuhkan perlindungan khusus, termasuk sebelum anak kembali ke keluarga dan masyarakat. Layanan shelter ini bersifat sementara dan dilakukan hanya bila penempatan anak di keluarganya membahayakan keselamatan anak atau bertentangan dengan prinsip kepentingan terbaik bagi anak. Ketiga, petugas pendampingan dilakukan oleh tim sesuai dengan kebutuhan pelayanan seperti; pekerja sosial, psikolog, dokter, guru, pengacara, polisi, guru agama dan lain-lain. Keempat, mengoordinasikan "peralihan" pelayanan anak dan keluarganya dari satu pelaksana layanan ke pelaksana layanan lainnya, termasuk pengendalian informasi dan dokumen yang dihasilkan dari setiap layanan. Kelima, pemenuhan kebutuhan dasar (pangan, sandang, kesehatan, psikososial, pendidikan), pemberdayaan keluarga, hukum dan temporary shelter yang disediakan baik oleh Lembaga Kesejahteraan Sosial Anak (LKSA) maupun lembaga jejaring lainnya. Keenam, melakukan dan mengoordinasikan assessment lanjutan secara berkala, sesuai tahap pelaksanaan pelayanan terhadap anak dan keluarganya.

Pada setiap tahap pelayanan tersebut, apabila dipandang perlu berdasar pertimbangan profesionalitas dan untuk kepentingan terbaik bagi anak, pekerja sosial dapat mengadakan case conference khusus guna membahas perkembangan khusus yang terjadi pada anak/keluarganya. Pada proses implementasi seorang pekerja sosial harus mampu menentukan jenis pelayanan yang dibutuhkan oleh anak. Proses tersebut harus berdasarkan aspek kepentingan terbaik untuk anak dengan melihat situasi dan kondisi. Pekerja sosial harus memperhatikan bahwa pemecahan masalah bukan hanya terkait dengan kasus anak akan tetapi juga bagaimana meningkatkan peran dan tanggung jawab keluarga serta masyarakat. Di samping itu pekerja sosial juga dituntut untuk mampu mendorong dan mempengaruhi kebijakan terutama meningkatkan upaya pencegahan dalam rangka meningkatkan tanggung jawab semua pihak dalam perlindungan anak serta membuat jejaring lembaga untuk mendukung intervensi yang dilaksanakan agar mencapai hasil yang maksimal.

\section{d. Evaluasi}

Pada tahap evaluasi adalah menelaah proses yang terjadi selama pelaksanaan pemberian pelayanan/intervensi yang perlu dilaksanakan secara berkala, bisa per bulan, per tiga bulan, enam bulan, atau satu tahun tergantung dari kompleksitas kasus dan waktu pemberian pelayanan yang telah ditetapkan 
dalam rencana. Monitoring dilaksanakan untuk mengetahui perkembangan hasil atau dampak yang tidak diharapkan dari pelaksanaan pelayanan yang sudah diberikan. Di samping mendeteksi sedini mungkin kendala/hambatan dalam pelaksanaan pemberian pelayanan dan kesesuaian layanan dengan harapan dan kebutuhan penerima manfaat. Pelaksanaan monitoring dilakukan guna menyediakan informasi umpan balik dini bagi pelayanan dan peringatan dini kepada penyedia pelayanan. Diharapkan dapat mendorong pengelolaan pelayanan yang lebih baik yang mengatasi kendala/hambatan dan meminimalkan risiko yang tidak diharapkan. Di sisi lain juga dapat meningkatkan efektivitas atau memaksimalkan manfaat yang diperoleh dari pelayanan dan meminimalkan kegagalan pelayanan. Monitoring dapat dilakukan oleh pekerja sosial atau menugaskan orang lain dan bekerja sama dengan tokoh masyarakat dan kelembagaan/organisasi yang terkait baik di tingkat lokal maupun yang lebih luas. Monitoring dapat dilakukan antara lain melalui home visit dengan wawancara, pengamatan, diskusi, atau dengan melakukan hubungan melalui telepon.

Agar mempermudah pelaksanaan monitoring perlu dirumuskan instrumen pengumpulan informasi yang bersandar pada dokumen rencana yang dapat menjadi alat untuk membandingkan kenyataan pelaksanaan kegiatan dengan standar/ harapan. Berdasarkan hasil monitoring kemudian dapat dirumuskan rekomendasi yang perlu ditindaklanjuti dalam pengelolaan kegiatan selanjutnya. Proses dan hasil monitoring perlu dilaporkan sebagai bentuk pertanggungjawaban kepada lembaga pelayanan dan didokumentasikan. Evaluasi dilakukan pada seluruh tahapan proses layanan manajemen kasus, dan hasil dari evaluasi menjadi bahan untuk mengukur indikator keberhasilan. Di samping untuk mengetahui kendala dan hambatan selama proses penanganan berlangsung, sebagai bahan perbaikan intervensi atau sebagai dasar pengakhiran pelayanan (terminasi).

\section{Peran Pekerja Sosial Menangani Anak yang Berkonflik dengan Hukum}

Tujuan akhir dari program penanganan terhadap ABH adalah untuk membantu mereka agar mampu membuat keputusan sendiri (help people to help themselves). Kunci agar pelayanan berjalan efektif terletak pada kemampuan pekerja sosial untuk menganalisis dan menetapkan prioritas kebutuhan serta mencapai beberapa keseimbangan dalam melakukan tugas secara berkesinambungan. Peran dan fungsi pekerja sosial dengan anak yang berkonflik dengan hukum, antara lain: case manager, assessor, perencana (planner), penghubung (broker), pembela (advocate), konduktor layanan (conductor), pengevaluasi (evaluator), fasilitator, pelatih (trainer), peneliti, pemberi informasi, partisipator, mobilisator, konsultatif, pemberdaya, negosiator dan peran kemitraan.

Sebagai case manager, pekerja sosial melakukan langkah-langkah dan proses interaksi dalam satu jejaring (network) pelayanan untuk memastikan seorang anak atau kelompok rentan mendapatkan pelayanan yang komprehensif, kompeten, efektif dan efisien. Manajemen kasus merupakan metode untuk memberikan berbagai pelayanan dimana seorang manajer kasus melakukan assessment kebutuhan anak dan keluarganya yang diperlukan untuk merancang, mengoordinasikan, mengadvokasi, memonitor, dan mengevaluasi berbagai pelayanan untuk memenuhi kebutuhan spesifik anak yang kompleks.

Sebagai seorang assessor, pekerja sosial mempunyai peran untuk melakukan kajian kerentanan serta melakukan diagnosis awal terhadap tingkat keselamatan anak dari ancaman tindak kekerasan, eksploitasi, penelantaran dan diskriminasi. Di samping itu pekerja sosial melakukan assessment terhadapkondisi ketersediaan dan kelayakan pelayanan yang ada maupun potensi 
dan sumber-sumber yang tersedia untuk merespon permasalahan anak. Sebagai seorang assessor, pekerja sosial mempunyai tugas: (1) melakukan verifikasi terhadap kasus yang masuk, baik dari hasil penjangkauan (outreach), rujukan (referral) dan laporan masyarakat untuk melihat urgensi masalah; (2) melakukan assessment kebutuhan anak, permasalahan anak, harapan-harapan anak, potensi, kapasitas anak; (3) melakukan assessment terhadap kondisi sosial ekonomi keluarga, kemampuan keluarga untuk memenuhi kebutuhan dasar anak, sistem pengasuhan, sistem nilai, potensi keluarga, permasalahan keluarga, kebutuhan keluarga, stabilitas dan konsistensi keluarga, sistem perlindungan anak; (4) melakukan assessment terhadap lingkungan: kondisi rumah, riwayat keluarga, keluarga dan kerabat, kondisi sosial ekonomi lingkungan, kondisi keamanan lingkungan, jejaring sosial dan kemampuan penyedia layanan sosial; serta (5) hasil assessment anak, keluarga dan lingkungannya digunakan sebagai dasar dalam penyusunan rencana yang akan dibahas dalam case conference.

Sebagai perencana (planner), pekerja sosial adalah seorang agen perubahan. Perubahan yang terjadi harus direncanakan dengan baik. Pekerja sosial menyusun perencanaan pelayanan yang dibutuhkan oleh anak dan keluarga berdasarkan hasil assessment termasuk melakukan pengembangan rujukan. Sebagai seorang perencana, tugas seorang pekerja sosial antara lain: (1) menyelenggarakan analisis tentang sumber dan potensi anak untuk dijadikan bahan dalam membuat program agar supaya program tersebut dapat dijalankan; (2) mengumpulkan data dan informasi dari berbagai sumber seperti: kepolisian, rumah sakit, LSM, guru, dan lain-lain yang terlibat dalam penanganan anak; (3) menganalisis data dan informasi yang telah dikumpulkan, selanjutnya melakukan pengembangan rencana pelayanan; (4) mengembangkan rencana pelayanan yang komprehensif meliputi tahap dan jenis pelayanan yang dibutuhkan anak, lembaga pelayanannya termasuk rencana monitoringnya, hasil yang diharapkan serta kerangka waktu pelaksanaannya; serta (5) mendorong keterlibatan profesi dari berbagai disiplin ilmu dan memaksimalkan keterlibatan anak dan keluarga.

Sebagai penghubung (broker), pekerja sosial menghubungkan anak dan keluarga pada pelayanan yang tersedia, serta mengupayakan kemudahan dalam mendapatkan pelayanan sosial dasar yang dibutuhkan, baik pelayanan formal dan informal. Sebagai seorang penghubung pekerja sosial bertugas: (1) menjelaskan kebutuhan spesifik anak kepada lembaga penyedia layanan; dan (2) memastikan anak dapat mengakses pelayanan.

Sebagai mediator, seorang pekerja sosial mempertemukan antara keluarga pelaku dan korban yang dihadiri tokoh masyarakat yang dianggap perlu untuk melakukan musyawarah dalam rangka mencapai restorative justice. Musyawarah keluarga dilakukan secara tertutup di tempat yang dapat menjamin kerahasiaan klien. Sebelum musyawarah dilakukan, mediator menjelaskan tujuan musyawarah keluarga kepada kedua belah pihak sehingga mereka betul-betul paham atas halhal yang ingin dicapai dalam musyawarah yang akan dilakukan. Masing-masing pihak diberikan kesempatan untuk menjelaskan kasus menurut versi masing-masing. Memotivasi pelaku dan keluarganya untuk meminta maaf secara lisan maupun tulisan kepada korban dan keluarga korban; juga memotivasi korban dan keluarga korban untuk memaafkan pelaku. Korban dan keluarganya diberi kesempatan untuk mengajukan permintaan upaya perbaikan, pengobatan atau penggantian kerugian atas kerusakan, kehilangan atau kecelakaan yang telah diakibatkan oleh tindakan pelaku. Pelaku dan keluarganya juga diberi kesempatan untuk menyatakan kesanggupannya. Kesempatan diberikan kepada keluarga korban dan pelaku untuk bernegosiasi menyepakati hal tersebut.

Sebagai pembela sosial (social advocate), pekerja sosial bertindak mewakili kepentingan anak dan keluarga untuk mendapatkan hak-haknya. Pekerja sosial juga memberikan masukan untuk perbaikan program dan kebijakan pelayanan 
bagi anak dan keluarga. Pekerja sosial dalam menangani anak yang berkonflik dengan hukum, perlu melakukan kolaborasi dengan profesi seperti pengacara. Pengacara adalah bagian dari pihak yang memberikan perlindungan hukum kepada anak yang berkonflik dengan hukum. Advokasi kepada aparat penegak hukum harus dilakukan oleh pekerja sosial, terutama menekankan kepada perlunya pemenuhan perlindungan sosial terhadap anak yang sedang ditahan atau dipenjara. Advokasi dilakukan kepada aparat penegak hukum di semua tingkatan, baik ketika masih pada tingkat penyidikan di kantor polisi maupun tingkat penuntutan. Fokus lain dari advokasi yaitu pekerja sosial mempengaruhi polisi pada tingkat penyidikan agar aparat kepolisian melakukan diversi, terutama untuk kasus-kasus dalam kategori "petty crime" (kejahatan sepele, remeh, kecil). Secara khusus tugas pekerja sosial sebagai advokat antara lain: (1) membantu menganalisis dan mengartikulasikan isu kritis yang berkaitan dengan anak maupun permasalahan-permasalahan yang terkait; (2) membantu anak untuk memahami dan melakukan refleksi atas isu tersebut untuk selanjutnya dijadikan lesson learn untuk melangkah dalam kehidupan selanjutnya; (3) membangkitkan dan merangsang diskusi dan aksi kegiatan yang berarti dalam rangka memperoleh dukungan dari berbagai pihak dalam penyelesaian masalah anak yang berkonflik dengan hukum; (4) bertindak atas kepentingan anak dan keluarganya untuk mendapatkan layanan sesuai dengan kebutuhannya; serta (5) menyampaikan saran perbaikan program, kebijakan pelayanan bagi anak dan keluarga kepada lembaga pelayanan dan pembuat kebijakan.

Sebagai konduktor layanan (conductor), pekerja sosial melakukan fungsi koordinasi dan juga menyinkronisasikan pelaksanaan layananlayanan agar sesuai dengan kebutuhan anak dan keluarga, dari sisi kualitas maupun waktu penyelenggaraannya. Sebagai seorang konduktor, pekerja sosial mempunyai tugas sebagai berikut: (1) memastikan berjalannya mekanisme koordinasi antar lembaga pemberi pelayanan yang terlibat dalam penanganan kasus anak; (2) mengorganisir penyelenggaraan kegiatan pembahasan kasus (case conference); (3) mengkoordinir penyimpanan secara detail seluruh data yang terkait proses pelayanan dan mengendalikan arus data sesuai dengan kepentingan kasus.

Sebagai pengevaluasi (evaluator), pekerja sosial melakukan monitoring dan evaluasi terhadap proses pelaksanaan pelayanan sampai pengakhiran layanan terhadap anak dan keluarga. Sebagai seorang evaluator, pekerja sosial mempunyai tugas sebagai berikut: (1) memantau pelaksanaan rencana pelayanan, status perkembangan, pelaksanaan pelayanan serta keterlibatan jejaring sosial lainnya dalam penanganan kasus anak; (2) mengevaluasi efektivitas pelaksanaan rencana pelayanan, dampak terhadap keberfungsian sosial anak, dukungan kapasitas dan jejaring sosial serta kemampuan penyedia layanan pada anak; dan (3) memastikan tersusunnya laporan penanganan kasus secara komprehensif.

Sebagai fasilitator, pekerja sosial bertanggung jawab dalam mempercepat usaha perubahan dengan mengajak orang-orang dan saluran komunikasi secara bersama-sama, menghubungkan aktivitas mereka dengan sumber-sumber, dan menyediakan akses terhadap berbagai bidang keahlian. Sebagai seorang fasilitator dalam menangani $\mathrm{ABH}$ antara lain: (1) membantu meningkatkan kemampuan anak agar hidup mandiri di masyarakat; (2) mempertinggi peran kelompok anak untuk bisa keluar dari permasalahannya, dengan membentuk peer support group (kelompok dukungan sebaya); dan (3) membantu anak untuk merespon interest masyarakat sehingga mereka dapat hidup bermasyarakat secara wajar.

Sebagai pelatih (trainer), seorang pekerja sosial merancang dan memberikan pelatihan keterampilan sosial kepada kelayan antara lain: (1) memperkirakan kebutuhan pelatihan bagi anak dan dibuat suatu program pelatihan yang cocok bagi mereka; (2) membantu merencanakan dan menyelenggarakan program pendidikan untuk meningkatkan kapabilitas anak; (3) membantu 
kelompok dukungan sebaya (peer support group) dalam melatih teman-teman lainnya; dan (4) membantu dalam pengembangan kelompok dukungan sebaya dalam hal keterampilan dan sikap untuk hidup bermasyarakat dan berorganisasi.

Sebagai peneliti, pekerja sosial bertanggung jawab terhadap pengembangan sebuah ilmu dalam praktek yang dikembangkannya. Pengalaman praktek adalah sebuah ilmu yang dapat dipelajari oleh teman sejawatnya. Sebagai seorang peneliti pekerja sosial melakukan: (1) menyelenggarakan analisis sosial yang berkaitan dengan isu anak yang berkonflik dengan hukum untuk membangun opini masyarakat yang positif karena masyarakat selama ini berpandangan negatif terhadap $\mathrm{ABH}$; (2) terlibat dalam penelitian participatory di mana kelompok dukungan sebaya belajar keterampilan untuk terlibat dalam pengumpulan data; (3) mempermudah konsep-konsep dan keterampilan penelitian yang tepat dengan tujuan agar konsep dan keterampilan tersebut berfungsi sebagai daya tarik bagi masyarakat umum dalam memahami konsep tersebut; dan (4) terlibat dalam integrasi sosial untuk memahami fenomena sosial dari sudut pandang dan pendirian anak yang berkonflik dengan hukum.

Sebagai pemberi informasi, merupakan serangkaian kegiatan yang dilakukan untuk memberikan penjelasan tentang kelembagaan, personel, kebijakan, program dan sumber pembangunan kesejahteraan sosial yang berkaitan dengan perubahan. Informasi yang disampaikan secara berkesinambungan dengan pesan dan media yang sesuai dengan karakteristik khalayak sasaran diharapkan mampu: (1) meredam berbagai bentuk keresahan yang diakibatkan oleh ketidakpastian sehubungan dengan aneka ragam persepsi; dan (2) meningkatkan pengertian, perhatian, kepedulian komitmen dan partisipasi pemilik sumber untuk mendukung pembangunan kesejahteraan sosial.

Sebagai partisipator, merupakan serangkaian kegiatan yang dilakukan untuk meningkatkan partisipasi dalam pembangunan kesejahteraan sosial. Kegiatan-kegiatan tersebut antara lain: (1) penyelenggaraan pertemuan-pertemuan berkala guna peningkatan kualitas personel, antara lain berupa diklat, seminar, lokakarya dan lain-lain; (2) penentuan bentuk-bentuk pelayanan sosial yang perlu dilaksanakan secara terkoordinasi; dan (3) peningkatan rujukan antar lembaga pelayanan yang dikelola, baik rujukan pelayanan maupun rujukan kelayan.

Sebagai mobilisator, pekerja sosial berusaha untuk menghimpun, pendayagunaan, mengembangkan dan mempertanggungjawabkan seluruh sumber-sumber yang ada guna mencapai kualitas pelayananyang optimal. Kegiatan yang dilaksanakan antara lain: (1) mendata dan menghimpun seluruh sumber yang ada. (2) menyeleksi dan menentukan sumber-sumber yang memungkinkan untuk didayagunakan; (3) mendayagunakan sumber terpilih; dan (4) bertanggungjawab terhadap hasil pendayagunaan sumber terpilih.

Sebagai konsultan, peran konsultatif merupakan serangkaian kegiatan yang dilakukan untuk mencegah dan mengatasi berbagai kendala yang dihadapi dalam pelaksanaan tugasnya serta memanfaatkan faktor-faktor pendukung atau peluang yang tersedia di dalam masyarakat. Kegiatan-kegiatan tersebut antara lain: (1) penyelenggaraan pertemuan-pertemuan konsultatif berkala dengan menghadirkan nara sumber/pakar terkait; (2) penyediaan konsultan yang ditugaskan untuk membantu dalam kaitan dengan tugasnya.

Sebagai pemberdaya, dengan menyelenggarakan serangkaian kegiatan yang dilakukan untuk meningkatkan kemampuan motivasi dalam pelaksanaan tugas-tugasnya. Kegiatan-kegiatan tersebut antara lain berupa: (1) penyelenggaraan pertemuan-pertemuan berkala guna peningkatan kualitas SDM antara lain berupa diklat, seminar, lokakarya baik di dalam maupun di luar negeri; (2) penyelenggaraan kunjungan studi banding ke daerah lain sesuai kebutuhan; (3) pendekatan persuasif untuk menggabungkan diri; dan (4) penyelenggaraan kampanye sosial kepada anak yang berkonflik dengan hukum secara berkala dan berkesinambungan melalui berbagai media masa.

Sebagai negosiator, pekerja sosial perlu 
menjalin hubungan dengan semua pihak yang terkait dengan kedudukan dan peranan jaringan kerja guna memperoleh dukungan kerja yang diperlukan. Kegiatan yang diperlukan antara lain: (1) mengidentifikasi pihak-pihak yang terkait dalam jaringan kerja; (2) mengadakan pendekatan dengan memberikan informasi tentang jaringan kerja yang perlu dibangun; dan (3) mengupayakan persetujuan dan dukungan untuk kelancaran proses jaringan kerja.

Peran kemitraan, merupakan serangkaian kegiatan yang dilakukan untuk meningkatkan kerja sama timbal balik yang saling menguntungkan dengan berbagai pemilik sumber guna peningkatan kemampuan, motivasi dalam pelaksanaan tugastugasnya. Kegiatan-kegiatan tersebut antara lain berupa: (1) penyelenggaraan pertemuan-pertemuan secara terencana dan berkala dengan para pemilik sumber, dengan menghadirkan nara sumber/ pakar terkait sebagai motivator; (2) penyediaan lahan-lahan pelayanan sosial profesional terpadu, misalnya pusat pelatihan keterampilan terpadu bagi anak yang berkonflik dengan hukum, yang dapat dikunjungi oleh pemilik sumber setiap waktu; dan (3) peningkatan kemampuan administrasi dalam pelaporan dan pertanggungjawaban penggunaan sumber yang diperoleh.

\section{Kesimpulan}

Permasalahan anak yang berkonflik dengan hukum tidak bisa diselesaikan dengan sembarangan atau tidak bisa dibiarkan begitu saja, tetapi harus diselesaikan secara profesional. Pekerjaan sosial adalah salah satu profesi pertolongan, yang salah satunya adalah pertolongan menangani permasalahan anak yang berkonflik dengan hukum. Pekerjaan sosial adalah aktivitas pertolongan untuk menolong individu-individu, kelompok-kelompok atau komunitas-komunitas agar dapat meningkatkan keberfungsian sosial dan menciptakan kondisikondisi masyarakat yang mendukung bagi pencapaian tujuan mereka.

Dengan demikian, tugas yang mendasar dari profesi ini adalah untuk menolong orang menemukan kebutuhan-kebutuhannya serta melaksanakan tanggung jawabnya sepanjang kehidupan mereka. Pekerjaan sosial menolong orang untuk meningkatkan keberfungsian mereka. Pertama kali yang harus dilakukan dalam menolong anak yang berkonflik dengan hukum adalah dengan memahami proses terbentuknya tingkah laku manusia. Hanya dengan hal tersebut maka pekerjaan sosial dapat mengaplikasikan teknik dan keterampilan untuk menolong klien dalam memutuskan memecahkan permasalahan mereka. Salah satu langkah yang paling pokok dalam proses pertolongan adalah assessment yang meliputi pengambilan keputusan tentang aspek-aspek apa dari tingkah laku atau situasi yang membutuhkan perubahan. Assessment di dalam pekerjaan sosial diarahkan pada keseluruhan aspek dari situasi anak yang berkonflik dengan hukum. Pekerja sosial mengonsentrasikan diri pada pemahaman tentang banyak aspek dari permasalahan khusus anak. Pekerja sosial melakukan assessment baik tentang perilaku anak sebagai individu maupun sistem sosial secara keseluruhan yang mempengaruhi anak yang meliputi keluarga, kelompok-kelompok dan lingkungan, lembaga-lembaga sosial, organisasi, ketetanggaan, komunitas-komunitas dan juga pemerintah baik di tingkat lokal, nasional dan bahkan internasional. intervensi yang dilakukan oleh pekerja sosial menyangkut dua hal pokok yaitu perilaku tindak kriminal anak dan faktor penyebab perilaku tersebut agar anak yang berkonflik dengan hukum dapat berfungsi sosial kembali dalam kehidupan bermasyarakat.

\section{DAFTAR PUSTAKA}

\section{A. Buku}

Cipriani, Don, 2009, Children's Rights and the Minimum Age of Criminal Responsibility a Global Perspective, Ashgate Publishing
Limited, Bulington.

Clinard, Marsal, et al., 2001, Sociology of Deviant Behavior, Wadsworth Cengage Learning, Belmont. 
Departemen Sosial RI, 2001, Intervensi Psikososial, Direktorat Kesejahteraan Anak, Jakarta.

Detrick, Sharon, et al., 2008, Violence Against Children in Conflict with the Law, Defence for Children International, Amsterdam.

Farrington, 1988, Youth Crime and Antisocial Behaviour, Psychology Press Ltd., Cambridge.

Gerungan, W. A., 1988, Psikologi Sosial, Eresco, Bandung.

Griffith, Currt T., et al., 2007, The Social Reintegration of Offenders and Crime Prevention, The International Center for Criminal Law Reform and Criminal Justice Policy (ICCLR), Ottawa.

Kerjasama Kementerian Pemberdayaan Perempuan dan Perlindungan Anak dengan Badan Pusat Statistik, 2011, Profil Anak Indonesia 2011, Miftahur Rizky, Jakarta.

Kurniasari, Alit, 2009, Profil Pendamping dalam Perlindungan Anak Berkonflik dengan Hukum, P3KS Press, Jakarta.

Midgley, James, 1995, Social Development: the Developmental Perspective in Social Welfare, SAGE Publications, London.

Terry, Mizrahi, et al., 2008, Encyclopaedia of Social Work, NASW Press, Washington.

NASW, 2005, NASW Standards for Social Work Practice in Child Welfare, NASW Press, Amerika.

O'loughlin, Mauren, et al., 2008, Transforming Social Work Practice, Social Work with Children and Families, Learning Matters Ltd., New York.

Salkind, Neil J., 2006, Encyclopedia of Human Development, Sage Publication and Thousand Oaks, London and New Delhi.

Sattler, Jerome M., 1992, Assesment of Children, Jerome M Sattler. Inc., California.

Shireman, Joan, 2003, Critical Issues in Child Welfare, Columbia University Press, New York.

Soekanto, Soerjono, 1990, Sosiologi Suatu Pengantar, Raja Grafindo Persada, Jakarta.
Sutarso, 2005, Praktek Pekerjaan Sosial dalam Pembangunan Masyarakat, Balatbangsos Departemen Sosial RI, Jakarta.

Charles, Zastrow, 2004, Introduction to Social Welfare, Thomson Brooks/Cole, Michigan.

Ward, Tony, et al., 2007, Human Rights and Correctional Clinical Practice, Elsevier, Melbourne.

\section{B. Laporan Hasil Penelitian}

Zulva, Eva Achjani, 2009, Keadilan Restoratif di Indonesia, Disertasi, Fakultas Hukum Universitas Indonesia, Jakarta.

Junus, Abdi Reza Fachlewi, 2012, Peran Jaksa dalam Menerapkan Konsep Diversi terhadap Anak yang Berkonflik dengan Hukum, Tesis, Fakultas Hukum Universitas Indonesia, Jakarta.

Rinita, 2012, Analisis Yuridis Penerapan Pemidanaan Edukatif terhadap Anak sebagai Pelaku Tindak Pidana, Tesis, Fakultas Hukum Universitas Indonesia, Jakarta.

Setyobudi, Mukhamad Tri, 2012, Pembinaan Anak Pidana di Lembaga Pemasyarakatan Anak Tangerang, Tesis, Fakultas Hukum Universitas Indonesia, Jakarta.

\section{Artikel Jurnal}

Smith, David, "Probation And Social Work", British Journal of Social Work, Vol. 7, Issue 4, 1977.

Sulhin, Iqrak, "Filsafat (Sistem) Pemasyarakatan", Jurnal Kriminologi Indonesia, Vol. 7, No.1, Mei 2010.

\section{Internet}

Direktorat Jenderal Pemasyarakatan (Ditjen PAS), Kementerian Hukum dan HAM, "Sistem Data Based Pemasyarakatan", http://smslap. ditjenpas.go.id/public/arl/current/monthly, diakses 21 Januari 2011.

Pusat Data dan Informasi Kementerian Sosial RI, "Data Penyandang Masalah Kesejahteraan Sosial Anak Nakal (AN)", http://www.kemsos. go.id/unduh/PMKS/Rekap_PMKS_2012.pdf, 
diakses 19 September 2014.

Khaeruddin, "Raju Masih Kecil Kok Sudah

Dipenjara?", http://sarapanpagi.fr.yuku.com/ topic/568/Raju-Masih-Kecil-Kok-SudahDipenjara, diakses 19 September 2014.

UNICEF, “Konvensi Hak Anak", http://www.unicef. org/magic/media/documents/CRC_bahasa_ indonesia_version.pdf, diakses 22 September 2014.

\section{E. Peraturan Perundang-Undangan}

Undang-Undang Nomor 23 Tahun 2002 tentang Perlindungan Anak (Lembaran Negara Republik Indonesia Tahun 2002 Nomor 109, Tambahan Lembaran Negara Republik Indonesia Nomor 4235).
Undang-Undang Nomor 11 Tahun 2012 tentang Sistem Peradilan Pidana Anak (Lembaran Negara Republik IndonesiaTahun 2012 Nomor 153, Tambahan Lembaran Negara Republik Indonesia Nomor 5332).

Kesepakatan Bersama Menteri Sosial RI, Menteri Hukum dan HAM RI, Menteri Pendidikan Nasional RI, Menteri Kesehatan RI, Menteri Agama RI dan Kepolisian Negara RI. (Nomor 12/PRS-2/KPTS/2009, Nomor M.HH.04. MH.03.02.Th.2009, Nomor 11/XII/KB/2009, Nomor 1220/Menkes/SKB/XII/2009, Nomor 06/XII/2009, Nomor B/43/XII/2009) tentang Perlindungan dan Rehabilitasi Sosial Anak yang Berhadapan dengan Hukum. 